\title{
Communication
}

\section{Remote Laser Induced Fluorescence of Soils and Rocks}

\author{
Vasily N. Lednev ${ }^{1, *}$, Alexey F. Bunkin ${ }^{1}$, Sergey M. Pershin ${ }^{1}$, Mikhail Ya. Grishin ${ }^{1}{ }^{\complement}$, Diana G. Artemova ${ }^{1}(\mathbb{D}$, \\ Vladimir A. Zavozin ${ }^{1}$, Pavel A. Sdvizhenskii ${ }^{1}$ (I) and Raul A. Nunes ${ }^{2}$ \\ 1 Prokhorov General Physics Institute, Russian Academy of Sciences, 38 Vavilova Street, \\ 117942 Moscow, Russia; abunkin@rambler.ru (A.F.B.); pershin@kapella.gpi.ru (S.M.P.); \\ mikhail.grishin@kapella.gpi.ru (M.Y.G.); artyomova_diana@mail.ru (D.G.A.); \\ vzavozin@kapella.gpi.ru (V.A.Z.); sdvizhenskii.pa@misis.ru (P.A.S.) \\ 2 Department of Materials Engineering, Pontifical Catholic University of Rio de Janeiro, Rua Marquês de São \\ Vicente, Rio de Janeiro 22541-041, Brazil; nunes@puc-rio.br \\ * Correspondence: lednev@kapella.gpi.ru; Tel.: +7-(499)-503-8777 (ext. 876)
}

Citation: Lednev, V.N.; Bunkin, A.F.; Pershin, S.M.; Grishin, M.Y.; Artemova, D.G.; Zavozin, V.A.; Sdvizhenskii, P.A.; Nunes, R.A. Remote Laser Induced Fluorescence of Soils and Rocks. Photonics 2021, 8, 411. https://doi.org/10.3390/ photonics 8100411

Received: 2 September 2021

Accepted: 20 September 2021

Published: 26 September 2021

Publisher's Note: MDPI stays neutral with regard to jurisdictional claims in published maps and institutional affiliations.

Copyright: (c) 2021 by the authors. Licensee MDPI, Basel, Switzerland. This article is an open access article distributed under the terms and conditions of the Creative Commons Attribution (CC BY) license (https:// creativecommons.org/licenses/by/ $4.0 /)$.

\begin{abstract}
The laser induced fluorescence spectroscopy was systematically utilized for remote sensing of different soils and rocks for the first time, to the best of our knowledge. Laser induced fluorescence spectroscopy measurements were carried out by the developed nanosecond LIDAR instrument with variable excitation wavelength (355, 532 and $1064 \mathrm{~nm})$. LIDAR sensing of different Brazil soil samples have been carried out in order to construct a spectral database. The laser induced fluorescence spectra interpretation for different samples has been discussed in detail. The perspectives of LIDAR sensing of organic samples deposited at soils and rock have been discussed including future space exploration missions in the search for extraterrestrial life.
\end{abstract}

Keywords: laser induced fluorescence; LIDAR; laser remote sensing; soil diagnostics; rocks fluorescence; biological pigments identification

\section{Introduction}

Extensive anthropogenic activities and fast growth of industry resulted in harsh exploitation of environment. Nowadays, ecological problems became very important so environmental pollution monitoring in real time is crucial for early detection of ecological problems to decreasing the possible negative impact. Specifically, anthropogenic activities are responsible for numerous cases of degradation and damage of soils [1] due to both harsh exploitation by farmers as well as to leaks of hazardous compounds (liquid and gas) from nearby industrial areas. Development of new techniques and instrumentation for monitoring atmosphere, water objects, soils and ground vegetation is of high demand [2-6]. The laser remote sensing is a powerful technique for express/online diagnostics of distant targets. The LIDAR (Light Detecting and Ranging) is a key instrument for laser remote sensing and such instruments utilize pulsed lasers to interact with the remote target and induce elastically and inelastically backscattered photons which provide information on some properties of the remote target. In 1970-1990s, LIDAR instruments were rather bulk and heavy $\left(>0.5 \mathrm{~m}^{3}\right.$ and $\left.>50 \mathrm{~kg}\right)$ so they were installed at stationary platforms so the range of possible objects of interest was rather limited: in the majority of cases it was lower and upper atmosphere sensing. LIDAR systems were also installed onboard of helicopters or airplanes but high cost of such aircraft vehicle exploitation resulted in very limited LIDAR applications: scientific studies, military applications or proof-of-concept demonstrations. In late 2010s, cost-saving unmanned aircraft vehicles (drones) capable of carrying up to few $\mathrm{kg}$ became available. Nowadays, drone exploitation costs are low, so compact and sensitive LIDAR systems are of high interest for numerous applications such as ecological monitoring or plant field diagnostics in agriculture [4,5,7-13]. LIDAR measurements are also of high interest for satellite remote sensing since satellite data needs calibration for reliable interpretation for ocean and vegetation mapping $[8,9,14-18]$. 
Numerous objects have been extensively studied by LIDARs $[4,9,14]$ but laser remote sensing of soils has not been systematically implemented so far [19-21]. Soils alteration by harsh exploitation or contamination cause biochemical changes in vegetation and hence quality of the produced food. Due to dynamic nature of soil contamination express and sensitive techniques are required for early monitoring in order to prevent intense or even inevitable problems. Fluorescence spectroscopy of soils has been extensively studied under laboratory conditions [22-25] and it was demonstrated that different pigments can be identified. Thus, soil microbiological activity and organic matter accumulation can be estimated and soil fertility can also be measured. In the present paper, we have developed a fluorescence LIDAR system for the remote sensing of soil and water surfaces as well as green vegetation from mobile carriers (helicopters, automobiles and ships). Both laboratory and field experiment results are discussed to illustrate the perspectives of laser remote sensing for express diagnostics of soils.

\section{Experiment Setup}

A scheme of the developed LIDAR system is presented in Figure 1. A specially designed Nd:YAG laser (pulse duration $8 \mathrm{~ns}$, pulse repetition rate up to $25 \mathrm{~Hz}$, fundamental harmonic $(\lambda=1064 \mathrm{~nm})$ pulse energy $600 \mathrm{~mJ}$, second harmonic $(\lambda=532 \mathrm{~nm})$ pulse energy $280 \mathrm{~mJ}$, third harmonic $(\lambda=355 \mathrm{~nm})$ pulse energy $100 \mathrm{~mJ})$ became the core element of the LIDAR instrument. We utilized custom design frequency converters based on potassium dihydrogen phosphate (KDP) crystals to generate the required wavelength while colored glass filters cleaned up the second and third harmonics. The laser was specifically developed for harsh exploitation with strong vibrations to provide long-term stable generation while operating the laser onboard of an aircraft. The laser beam was directed by an aluminum coated plane mirror to the remote target (ground, water or vegetation). The backscattered photons were collected by the same mirror and reflected to the telescope $(200 \mathrm{~mm}$ in diameter, aperture of $1 / 3)$ which focused the irradiation to the input slit of the polychromator (assembled as an autocollimator). The different diffraction gratings (300 and 1200 lines per $\mathrm{mm}$ ) can be used depending on required spectral resolution. In the first diffraction order of the polychromator (300 lines $/ \mathrm{mm}$ grating) the single-measurement spectral window was $525 \mathrm{~nm}$ with $0.5 \mathrm{~nm}$ spectral resolution, which was sufficient to record broadband fluorescence spectra of soils. By rotating the spectrograph's diffraction grating spectral regions of interest can be chosen. In order to protect the detector from elastically scattered laser pulse we utilized notch filters installed at the polychromator input. Polychromator can be also used at higher orders for spectral gratings (up to 9th). In such case spectral resolution will be $0.022 \mathrm{~nm}$ per channel, so fine spectral lines in laser plasma can be distinguished, thus elemental analysis by laser induced breakdown spectroscopy can also be carried out [26]. A sensitive gated linear CCD camera (1024 pixels) was utilized for spectra quantification in 350-900 nm spectral range. The camera's intensifier provided strong amplification up to $3 \times 10^{4}$ so every 10 captured photons were quantified as one digital count. The minimum gate can be set to $10 \mathrm{~ns}$ thus the LIDAR can be exploited at any solar illumination conditions. The G-56 pulse generator was used to synchronize the Nd:YAG laser triggering and gated camera acquisition while a personal computer captures and stores the backscattered spectra. Based on the developed LIDAR parameters we estimated that ground areas about $1 \mathrm{~m}^{2}$ can be sampled sequentially from a height of 300-500 m.

The developed LIDAR was designed to be utilized during field campaign in different regions of Brazil. In order to test the instrument in the laboratory we have measured a few hundred different soil and rock samples originating from various regions of Brazil. Measurements were performed under daylight conditions since gated laser induced fluorescence spectroscopy acquisition (gate 10-50 ns) were not affected by the sunlight. 


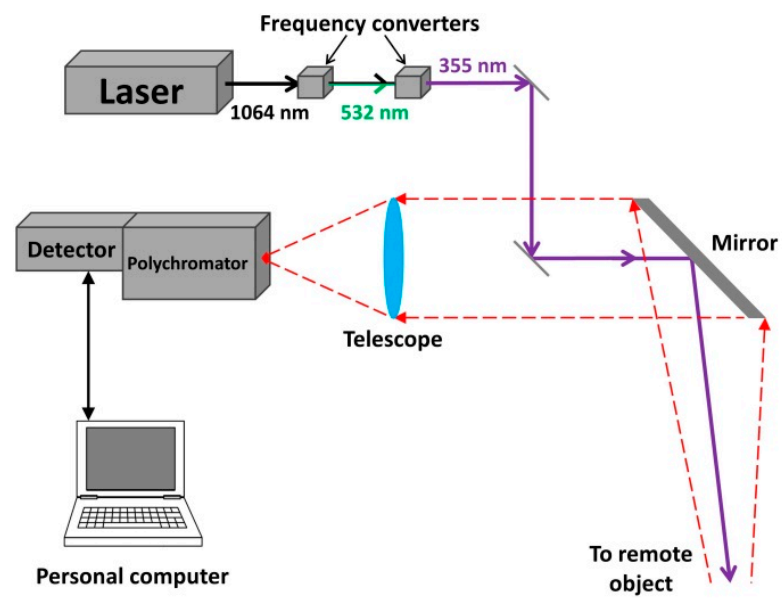

Figure 1. Experimental setup scheme of the LIDAR instrument for laser remote sensing of soils.

\section{Results}

Examples of the fluorescence spectra induced by $355 \mathrm{~nm}$ excitation for soil samples are presented in Figure 2. For comparison, return signal spectra of seawater and ground vegetation are also shown. The fluorescence spectra of all the studied samples have characteristic peaks in blue and green bands. A systematic study of more than 500 samples including soils, vegetation and seawater has been carried out to construct laser induced fluorescence spectra database. Laser induced fluorescence spectra contain different characteristic bands in blue, green and red spectral regions depending on the sample. Concerning soil sample bands in fluorescence spectra were attributed to amino acids, nucleic acids and some of the coenzymes: the reduced form of nicotinamide adenine dinucleotide (NADH) and its phosphate (NADPH), flavins (flavin mononucleotide and flavin adenine dinucleotide) and the vitamins [27]. These compounds have a high fluorescence quantum yield so they are most intense in the spectra. Furthermore, phytofluene (hexahydrolycopene, partially hydrogenated pigment from carotenoid group) and perylene (aromatic hydrocarbon of five condensed benzene rings) also contribute to the blue band. The latter compound is found in arid soil and volcano eruption products [28,29]. The green spectral band was attributed to 1,4-dihydroxyanthraquinones [30], which are of microscopic fungi origin always presented in soils.
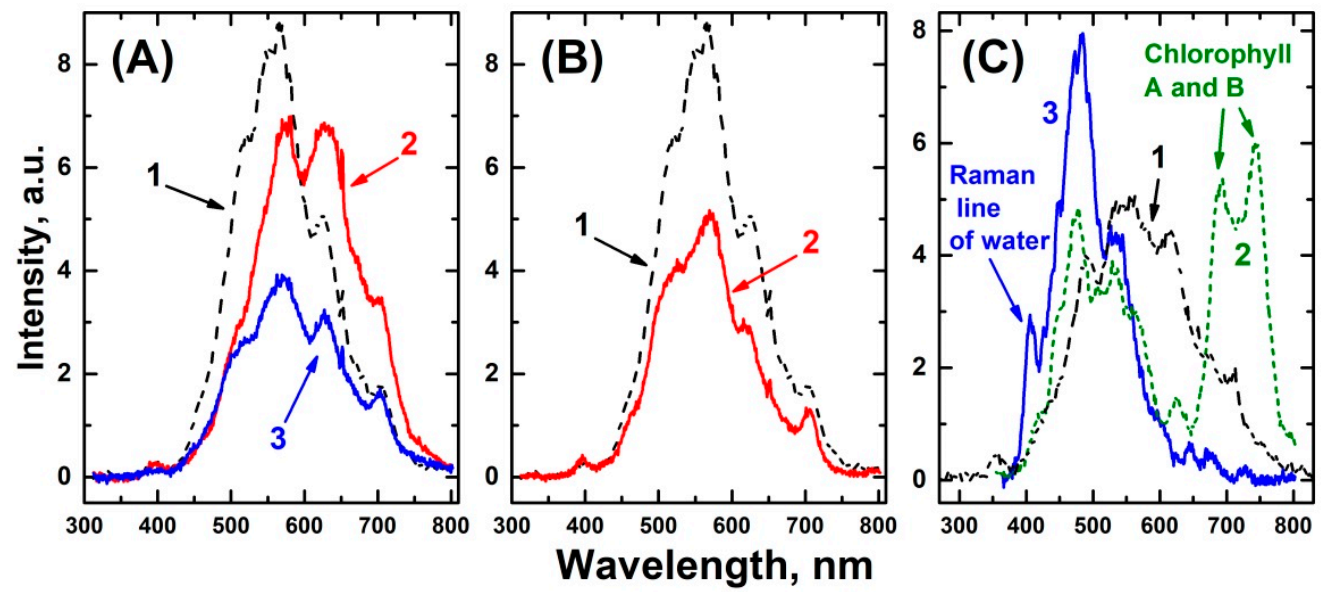

Figure 2. Laser induced fluorescence spectra of soils with the $\lambda=355 \mathrm{~nm}$ excitation. (A) soil from various Brazil regions: Amazonas (1) and Rio Grande do Sul (2) States and the Cape Cabo Frio (3). (B) Soil samples of Amazonas State from depths 0-6 (1) and 92-134 cm (2). (C) Upper soil of Mato Grosso do Sul State (1), leaf of Brazilian acacia Pao Brasil (2) and seawater of coastal area near Leme beach, Copacabana, city of Rio de Janeiro (3). Spectrum (3) exhibits known fluorescence peaks of chlorophylls A and B, seen also in (2), as well as the Raman peak of seawater. 
These results clearly demonstrated that the developed LIDAR can detect different organic compounds in soils, sediment rock, natural water, including living microorganism cells, green leaves of plants and sea plankton [10,31,32]. Preliminary data on the analyzed fluorescence spectra of soil, seawater, vegetation and synthetic samples are summarized in Table 1. According to the presented data, both pterin and flavin compounds can be identified, but these two classes of coenzymes are principally important for living organisms. Therefore, this instrument can be employed for the remote sensing search of life traces (chemical evidence "prints" of ancient life in Precambrian rock, organic materials of space origin etc.) in future extraterrestrial missions.

Table 1. Fluorescence maxima of natural and synthetic samples, measured by the fluorescence LIDAR $(\lambda=355 \mathrm{~nm}$ excitation).

\begin{tabular}{|c|c|c|}
\hline No. & $\lambda, \mathrm{nm}$ & Sample Characteristic \\
\hline 1 & $475-480$ & 6,7-dimethyl pterin adsorbed on kaolinite \\
\hline 2 & $475-480$ & NADH on kaolinite \\
\hline 3 & $475-480$ & Complex of abiogenic pterins $\left(8: 3: 1,185^{\circ} \mathrm{C}, 8 \mathrm{~h}\right)$ \\
\hline 4 & $475-480$ and $500-520$ & Same, but $6 \mathrm{~h}$ \\
\hline 5 & $475-480$ & $\mathrm{X}$ anthopterin from mixture 8:3:1 $(6 \mathrm{~h})$ \\
\hline 6 & $480-520$, broad band & Pterins + flavin in a wet synthetic product $(8: 3: 1,8 \mathrm{~h})$ \\
\hline 7 & 550 & Riboflavin on kaolinite \\
\hline 8 & 530 & $\begin{array}{l}\text { 1,4-dihydroxyanthraquinones from Penicillium funiculosum } \\
\text { (on kaolinite) }\end{array}$ \\
\hline 9 & $475-480$ & Lipid extract from brown oak leaves \\
\hline 10 & $475-480$ & Dry leaf (powder) of Amaranthus cruentus \\
\hline 11 & $475-480$ and $500-520$ & Green leaf (NADH+pterins) \\
\hline 12 & $475-480$ and $500-520$ & Dark soil, Moscow Region (pterins) \\
\hline 13 & 480-520, wide band & Pleistocene algal fossil rock, Crimea, $100,000 \mathrm{yr}$ \\
\hline 14 & $475-480$ & Juvenile ashes of the Tyatya Volcano eruption of 1973 (perylen) \\
\hline 15 & 520 and 550 & Latosole from the Amazon area, Brazil \\
\hline 16 & 475 and 550 & Green leaf Pao Brazil \\
\hline 17 & 475 and 550 & Seawater, Brazil \\
\hline
\end{tabular}

In order to estimate the capability of LIDAR "life markers" detection the following experiment has been carried out. Two $1 \mathrm{~cm}^{2}$ areas were sampled by the LIDAR for the ancient fern print at rock plate (see Figure 3a): inside and outside it. The distance between their centers did not exceed $1.5 \mathrm{~cm}$. Figure $3 \mathrm{~b}$ shows the corresponding laser induced fluorescence spectra normalized to the return signal at $\lambda=355 \mathrm{~nm}$ (elastic scattering of the probing beam). Preliminary experiments have revealed that the spectra do not vary significantly within a probed area both outside and inside the print. However, Figure $3 \mathrm{~b}$ exhibits an additional signal intensity in the range 540-560 $\mathrm{nm}$ when probing the relic print. This spectral band enhancement for the fern print can be explained by the condensed $\pi$-electron aromatic structures whose analogs are soil humins and rock kerogens. Detection and selection of such a signal during laser remote sensing of paleoarcheologic places of interest will indicate the areas which should be extensively searched in order to reveal the traces of ancient vegetation (and civilization). Of particular interest is that the same technique can be utilized for life markers detection during extraterrestrial missions on Mars, Venus or Jupiter's moon Europe [33-36]. It should be noted that fluorescence spectra features transform with time as the organic pigment molecules undergo decomposition. 
Laser induced fluorescence spectra features comparison can be potentially applied as a remote technique for estimating organic pigments age.
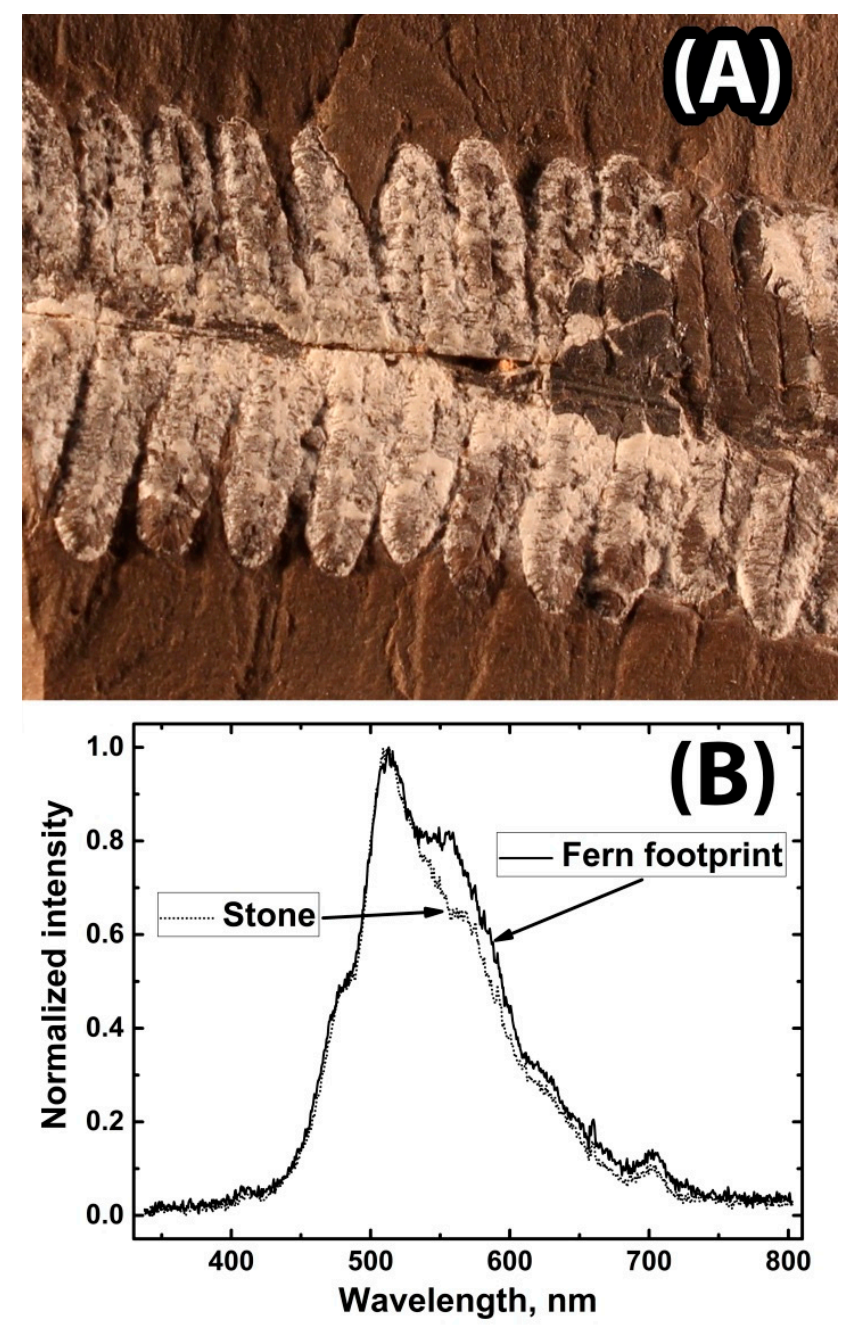

Figure 3. Laser induced fluorescence sensing of ancient fern print at a rock plate: (A) photograph and (B) fluorescence spectra of the stone inside and outside the print.

Table 2 summarizes the results for laser induced fluorescence spectroscopy with different excitation wavelengths. According to the presented table, excitation by $355 \mathrm{~nm}$ wavelength is not optimal in some cases for soil component identification. For example, detection of tetrapyrrole pigments (chlorophylls, phycoerythrins and phycocyanins) is not reliable for $355 \mathrm{~nm}$ excitation since these pigments have a low quantum yield at this wavelength and their emission can be totally overlapped with that for flavins and 1,4dihydroxyanthraquinones. However, in this case, the second harmonic $(\lambda=532 \mathrm{~nm})$ of the $\mathrm{Nd}$ :YAG laser can be efficiently used as a probing beam as it was previously demonstrated for laser remote sensing of the upper ocean $[3,4]$.

Undoubtedly, humic materials (humic and fulvic acids) also contribute to the soil fluorescence spectra. However, their emission is masked by that from vegetative and microbial pigments if they exist in the sample as it was shown previously for humic acids (HA) and their fractions fluoresce in alkaline solutions [37-39]. According to our data, HA (purified from low-molecular fluorescent impurities) have a blue-green emission with maxima at 465 and $540 \mathrm{~nm}$ wavelengths. Nearly the same spectral characteristics are inherent to soluble vegetative lignine and model humin-like polymers [40]. Fluorescence of humic acids and humin is related to the excitation of $\pi$-electron systems in aromatic condensed rings whose amount can even increase during sample pyrolysis [41]. 
Table 2. Fluorescence compounds (pigments) in soil and their spectral characteristics.

\begin{tabular}{|c|c|c|c|}
\hline Pigment & Excitation, $\mathrm{nm}$ & Emission, $\mathrm{nm}$ & Solvent \\
\hline $\begin{array}{l}\text { Benzene rings (anthracenes) } \\
\text { and heterocycles }\end{array}$ & $260-280$ & $340-360$ & Benzene, ethanol \\
\hline Phytofluene (hexahydrolycopene) & $\begin{array}{l}\text { 350-370; in the excitation } \\
\text { spectrum are bands at } 310,350 \\
\text { and } 370 \mathrm{~nm}\end{array}$ & 415 & Hexane \\
\hline Perylene & $\begin{array}{l}420 \text {; in the spectrum are bands } \\
\text { at } 370,385,405 \text { and } 434 \mathrm{~nm}\end{array}$ & 440 and 465 & Hexane, heptane \\
\hline \multirow[t]{2}{*}{ Flavonols (3-hydroxyflavones) } & 370 & $470-520$ & Ethanol \\
\hline & 440 & $520-540$ & Ethanol $+\mathrm{H}_{3} \mathrm{BO}_{3}+$ citrate \\
\hline $\begin{array}{l}\text { 2-hydroxy-5-methyl-1,4- } \\
\text { benzoquinone }\end{array}$ & $370-390$ & $480-500$ & $\begin{array}{c}\text { Ethanol; in } 0.1 \mathrm{~N} \mathrm{KOH} \text { absorbs } \\
\text { at } 510 \mathrm{~nm}\end{array}$ \\
\hline Leucopterin & 355 & 430 & $\begin{array}{l}\text { Ethanol, pH 9.0; (2-amino- } \\
\text { 4,6,7-trihydroxypteridine) }\end{array}$ \\
\hline $\begin{array}{l}\text { Xanthopterin, isoxanthopterin } \\
\text { (2-amino-4,6-dihydroxypteridine and } \\
\text { 2-amino-4,7-dihydroxypteridine) }\end{array}$ & 375 & $460-480$ & Same \\
\hline $\begin{array}{l}\text { NADH and NADPH in living } \\
\text { microorganism cells and leaves }\end{array}$ & 340 & 455,480 & Water, pH 7.0 \\
\hline $\begin{array}{l}\text { Flavins (riboflavin, lumiflavin, } \\
\text { lumichrome; flavin mononucleotide } \\
\text { and flavin adenine dinucleotide) }\end{array}$ & $370($ or 450$)$ & $500-530$ & Ethanol, $\mathrm{CHCl}_{3}$ \\
\hline \multirow[t]{2}{*}{ 1,4-dihydroxyanthraquinones } & 370 & $500-540$ & Ethanol $\mathrm{CH}_{3} \mathrm{COOH}$ \\
\hline & 500 & $640-660$ & $\begin{array}{c}\text { A complex with } \\
\left(\mathrm{CH}_{3} \mathrm{COO}\right)_{2} \mathrm{Mg} \text { in ethanol }\end{array}$ \\
\hline Chlorines (related to chlorophylls) & 420 & 672,715 & Ethanol \\
\hline Phycoerythrins & 500 & $580-630$ & Water \\
\hline Phycocyanobilins & 600 & $660-715$ & Water \\
\hline Phycobilins-655 & $580-600$ & 665 & 2,6-lutidine, amyl alcohol \\
\hline 4,9-dihydroxyperylene-3,10-quinone & $500-520$ & $660-670$ & In concentrated $\mathrm{H}_{2} \mathrm{SO}_{4}$ \\
\hline
\end{tabular}

Intense blue-green fluorescence bands in the studied soil samples are attributed to pterin [41] and flavin [42,43] coenzymes, which had a fluorescence similar to that for Euglena gracilis seaweed [44]. The LIDAR was able to detect pigments immediately onsite in its native form. The conventional laboratory techniques require time consuming sampling, transportation, chromatographic separation and purification, so the original sample can be slightly or moderately damaged or modified during this period. For example, the fluorescence spectra of pigments in native form have a moderate red shift (by 10-20 nm) compared to their spectra in an organic solvent [45-49]. The "host" effect can affect not only the afterglow maximum position but also the quantum yield, when the pigment system of cells exhibits intermolecular migration of excitation. For instance, if the samples were not properly transported and handled then fluorescent compounds can transfer the absorbed quantum energy to chlorophyll, exciting or amplifying its fluorescence. The model membrane-like structure containing phycobilin and flavin pigments exhibits the transfer of light energy absorbed by phycobilin in the red band to the flavin reactivity center [44]. These effects can complicate the interpretation of fluorescence spectra, therefore additional chemical analysis is required in some cases. 


\section{Conclusions}

The principle of LIDAR instrument is based on remote sensing by laser photons which induce fluorescence and backscattered photons that provide information on the object of interest. Here, we presented a multi-wavelength pulsed LIDAR instrument which was used for a systematic study of laser induced fluorescence of different soils. Due to high sensitivity and optimal choice of pumping wavelength, the developed LIDAR is able to identify the majority of most important soil pigments as well as cell pigment systems (pterins and flavins) allowing one acquiring virtually instantaneously the information on pigments in natural objects. We have demonstrated that the LIDAR instrument is an effective and powerful tool for remote monitoring of soil and water contamination by different agents (oil and oil products, organic industrial production pollutants, heavy metals, etc.). Alternatively, the LIDAR technology is perspective for searching ancient organic matter deposits and in life traces detection in ongoing and future extraterrestrial missions [50,51]. It should be noted that the two color (in/outside Chl-a absorption band) analysis of Mars images acquired by satellite multispectral cameras is very informative for preliminary estimation of perspective landing sites with organic pigments $[52,53]$ and surface humidity [54]. A new generation of compact eye-safe LIDAR instruments [55-58] is of growing interest for development of numerous applications and control systems which can be safely exploited in inhabited places (city streets, airport, train station, etc.) without any risks of eye damage.

Author Contributions: V.N.L., writing—review and editing; A.F.B., conceptualization, project administration, writing — original draft preparation, supervision; S.M.P., conceptualization, writingoriginal draft preparation; M.Y.G., visualization and language check; D.G.A., writing—review and editing; V.A.Z., visualization; P.A.S., software; R.A.N., project administration, supervision. All authors have read and agreed to the published version of the manuscript.

Funding: This work was supported by a grant of the Ministry of Science and Higher Education of the Russian Federation (075-15-2020-912) for the organization and development of a World-class research center "Photonics".

Institutional Review Board Statement: Not applicable.

Informed Consent Statement: Not applicable.

Data Availability Statement: Not applicable.

Conflicts of Interest: The authors declare no conflict of interest.

\section{References}

1. Götze, C.; Beyer, F.; Gläßer, C. Pioneer vegetation as an indicator of the geochemical parameters in abandoned mine sites using hyperspectral airborne data. Environ. Earth Sci. 2016, 75, 613. [CrossRef]

2. Lassalle, G.; Fabre, S.; Credoz, A.; Dubucq, D.; Elger, A. Monitoring oil contamination in vegetated areas with optical remote sensing: A comprehensive review. J. Hazard. Mater. 2020, 393, 122427. [CrossRef] [PubMed]

3. Measures, R.M. Laser Remote Sensing: Fundamentals and Applications; John Wiley \& Sons, Ltd.: New York, NY, USA, 1984; ISBN 0894646192.

4. Bunkin, F.A.; Voliak, K. Laser Remote Sensing of the Ocean: Methods and Applications; John Wiley \& Sons, Ltd.: New York, NY, USA, 2001; ISBN 0471389277.

5. Pershin, S.M.; Grishin, M.Y.; Zavozin, V.A.; Lednev, V.N.; Lukyanchenko, V.A.; Makarov, V.S. Aerosol layers sensing by an eye-safe lidar near the Elbrus summit. Laser Phys. Lett. 2020, 17, 26003. [CrossRef]

6. Bukin, O.; Proschenko, D.; Alexey, C.; Korovetskiy, D.; Bukin, I.; Yurchik, V.; Sokolova, I.; Nadezhkin, A. New Solutions of Laser-Induced Fluorescence for Oil Pollution Monitoring at Sea. Photonics 2020, 7, 36. [CrossRef]

7. Bunkin, A.F.; Davydov, M.A.; Rezov, A.V.; Surovegin, A.L.; Tsipenyuk, D.Y. Helicopter-based LIDAR complex for emission and fluorescence remote sensing of terrain surface. Laser Phys. 1994, 4, 1198-1201.

8. Angelini, F.; Colao, F. Optimization of laser wavelength, power and pulse duration for eye-safe Raman spectroscopy. J. Eur. Opt. Soc. Publ. 2019, 15, 1-8. [CrossRef]

9. Churnside, J.H. Review of profiling oceanographic lidar. Opt. Eng. 2014, 53, 51405. [CrossRef]

10. Barbini, R.; Colao, F.; Fantoni, R.; Palucci, A.; Ribezzo, S. Differential lidar fluorosensor system used for phytoplankton bloom and seawater quality monitoring in Antarctica. Int. J. Remote Sens. 2001, 22, 369-384. [CrossRef] 
11. Churnside, J.H.; Marchbanks, R.D.; Lee, J.H.; Shaw, J.A.; Weidemann, A.; Donaghay, P.L. Airborne lidar detection and characterization of internal waves in a shallow fjord. J. Appl. Remote Sens. 2012, 6, 63611. [CrossRef]

12. Alimov, V.S.; Kosachev, V.D.; Danilov, B.O.; Zhevlakov, P.A.; Kashcheev, V.S.; Mak, A.A.; Petrov, B.S.; Ustyugov, I.V. Aviation Raman lidar with ultraspectral resolution. J. Opt. Technol. 2009, 76, 199-207. [CrossRef]

13. Raimondi, V.; Palombi, L.; Lognoli, D.; Masini, A.; Simeone, E. Experimental tests and radiometric calculations for the feasibility of fluorescence LIDAR-based discrimination of oil spills from UAV. Int. J. Appl. Earth Obs. Geoinf. 2017, 61, 46-54. [CrossRef]

14. Babichenko, S. Laser remote sensing of the European marine environment: LIF technology and applications. In Remote Sensing of the European Seas; Springer: Dordrecht, The Netherlands, 2008; pp. 189-204.

15. Richardson, S.D. Water analysis: Emerging contaminants and current issues. Anal. Chem. 2009, 81, 4645-4677. [CrossRef]

16. Brown, C.E.; Fingas, M.F. Review of the development of laser fluorosensors for oil spill application. Mar. Pollut. Bull. 2003, 47, 477-484. [CrossRef]

17. Babichenko, S.; Poryvkina, L.; Rebane, O.; Sobolev, I. Compact HLIF LiDAR for marine applications. Int. J. Remote Sens. 2016, 37, 3924-3937. [CrossRef]

18. Fantoni, R.; Almaviva, S.; Caneve, L.; Colao, F.; De Collibus, M.F.; De Dominicis, L.; Francucci, M.; Guarneri, M.; Lazic, V.; Palucci, A.; et al. In situ and remote laser diagnostics for material characterization from plasma facing components to Cultural Heritage surfaces. J. Instrum. 2019, 14, C07004. [CrossRef]

19. Gholizadeh, A.; Kopačková, V. Detecting vegetation stress as a soil contamination proxy: A review of optical proximal and remote sensing techniques. Int. J. Environ. Sci. Technol. 2019, 16, 2511-2524. [CrossRef]

20. Kuenzer, C.; Ottinger, M.; Wegmann, M.; Guo, H.; Wang, C.; Zhang, J.; Dech, S.; Wikelski, M. Earth observation satellite sensors for biodiversity monitoring: Potentials and bottlenecks. Int. J. Remote Sens. 2014, 35, 6599-6647. [CrossRef]

21. Pause, M.; Schweitzer, C.; Rosenthal, M.; Keuck, V.; Bumberger, J.; Dietrich, P.; Heurich, M.; Jung, A.; Lausch, A. In situ/remote sensing integration to assess forest health-A review. Remote Sens. 2016, 8, 471. [CrossRef]

22. Kolesnikov, M.P.; Egorov, I.A. Porphyrins and phycobilins in precambrian rocks. Orig. life Evol. Biosph. 1977, 8, 383-390. [CrossRef]

23. Kolesnikov, M.P. Molecular-Weight Distribution of Humic Acids, According To Gel Chromatography on Sephadexes. Sov. SOIL Sci. 1978, 10, 174-181.

24. Kolesnikov, M.P.; Egorov, I.A. Linear Tetrapyrroles as Biomarkers in Paleo-Biochemical Investigations. J. Inf. Technol. Constr. 1977, 233, 970-973.

25. Kolesnikov, M.P.; Egorov, I.A. Chlorophyll Derivatives in Recent Soils In Connection With Problem of Chemical Evolution And Origin Of Life On Earth. Dokl. Akad. Nauk SSSR 1977, 235, 228-231.

26. Lee, J.K.; Park, Y.; Bunkin, A.; Nunes, R.; Pershin, S.; Voliak, K. Helicopter-based lidar system for monitoring the upper ocean and terrain surface. Appl. Opt. 2002, 41, 401-406. [CrossRef] [PubMed]

27. Pan, Y.-L. Detection and characterization of biological and other organic-carbon aerosol particles in atmosphere using fluorescence. J. Quant. Spectrosc. Radiat. Transf. 2015, 150, 12-35. [CrossRef]

28. Kolesnikov, M.P. Flavonoids and Perylene in Soils. Eurasian Soil Sci. 1992, 24, 38-46.

29. Kolesnikov, M.P.; Egorov, I.A. Metalloporphyrins in The Precambrian Deposits As Probable Evidences Of The Ancient Photosynthesis. Dokl. Akad. Nauk SSSR 1979, 244, 470-473.

30. Capps, R.N.; Vala, M. Luminescence studies of quinizarin and daunorubicin. Photochem. Photobiol. 1981, 33, 673-682. [CrossRef]

31. Burikov, S.A.; Klimov, D.V.; Litvinov, P.N.; Maslov, D.V.; Fadeev, V.V. Shore-based lidar for monitoring coastal sea water areas. Quantum Electron. 2001, 31, 745. [CrossRef]

32. Barbini, R.; Colao, F.; Fantoni, R.; Fiorani, L.; Palucci, A.; Artamonov, E.S.; Galli, M. Remotely sensed primary production in the western Ross Sea: Results of in situ tuned models. Antarct. Sci. 2003, 15, 77-84. [CrossRef]

33. Maurice, S.; Wiens, R.C.; Bernardi, P.; Caïs, P.; Robinson, S.; Nelson, T.; Gasnault, O.; Reess, J.-M.; Deleuze, M.; Rull, F.; et al. The SuperCam Instrument Suite on the Mars 2020 Rover: Science Objectives and Mast-Unit Description. Space Sci. Rev. 2021, 217, 47. [CrossRef]

34. Sandford, M.W.; Misra, A.K.; Acosta-Maeda, T.E.; Sharma, S.K.; Porter, J.N.; Egan, M.J.; Abedin, M.N. Detecting Minerals and Organics Relevant to Planetary Exploration Using a Compact Portable Remote Raman System at 122 Meters. Appl. Spectrosc. 2021, 75, 299-306. [CrossRef]

35. Nurul Abedin, M.; Bradley, A.T.; Ismail, S.; Sharma, S.K.; Sandford, S.P. Compact remote multisensing instrument for planetary surfaces and atmospheres characterization. Appl. Opt. 2013, 52, 3116-3126. [CrossRef]

36. Abedin, M.N.; Bradley, A.T.; Sharma, S.K.; Misra, A.K.; Lucey, P.G.; McKay, C.P.; Ismail, S.; Sandford, S.P. Mineralogy and astrobiology detection using laser remote sensing instrument. Appl. Opt. 2015, 54, 7598-7611. [CrossRef] [PubMed]

37. Miano, T.M.; Martin, J.P.; Sposito, G. Flourescence spectroscopy of humic substances. Soil Sci. Soc. Am. J. 1988, 52, 1016-1019. [CrossRef]

38. Aiken, G. Fluorescence and dissolved organic matter: A chemist's perspective. In Aquatic Organic Matter Fluorescence; Cambridge University Press: Cambridge, UK, 2014; pp. 35-75.

39. Enev, V.; Pospíšilová, L.; Klučáková, M.; Liptaj, T.; Doskočil, L. Spectral characterization of selected humic substances. Soil Water Res. 2014, 9, 9-17. [CrossRef] 
40. Miano, T.; Sposito, G.; Martin, J.P. Fluorescence spectroscopy of model humic acid-type polymers. Geoderma 1990, 47, 349-359. [CrossRef]

41. Khodorenko, N.D.; Volkova, T.I.; Zvalinskii, V.I.; Tishchenko, P.Y. Extraction kinetics and quantitative analysis of bottom sediments for humic substances. Geochem. Int. 2012, 50, 385. [CrossRef]

42. Oesterhelt, D. The Biology of Photoreception; Cosens, D.J., Vince-Price, D., Eds.; Cambridge University Press: New York, NY, USA, 1983; pp. 207-222. Available online: https:/ / books.google.ru/books?id=LJrlzQEACAAJ (accessed on 16 September 2021).

43. Kritsky, M.S.; Telegina, T.A.; Vechtomova, Y.; Kolesnikov, M.P.; Lyudnikova, T.A.; Golub, O.A. Excited flavin and pterin coenzyme molecules in evolution. Biochemistry 2010, 75, 1200-1216. [CrossRef] [PubMed]

44. Sineshchekov, V.A.; Geiß, D.; Sineshchekov, O.A.; Galland, P.; Senger, H. Fluorometric characterization of pigments associated with isolated flagella of Euglena gracilis: Evidence for energy migration. J. Photochem. Photobiol. B Biol. 1994, 23, 225-237. [CrossRef]

45. Mirkovic, T.; Ostroumov, E.E.; Anna, J.M.; van Grondelle, R.; Govindjee; Scholes, G.D. Light Absorption and Energy Transfer in the Antenna Complexes of Photosynthetic Organisms. Chem. Rev. 2017, 117, 249-293. [CrossRef]

46. Cederstrand, C.N.; Rabinowitch, E. Govindjee Absorption and fluorescence spectra of spinach chloroplast fractions obtained by solvent extraction. Biochim. Biophys. Acta-Biophys. Incl. Photosynth. 1966, 120, 247-258. [CrossRef]

47. Macintyre, H.L.; Lawrenz, E.; Richardson, T.L. Chlorophyll a Fluorescence in Aquatic Sciences: Methods and Applications; Springer: Dordrecht, The Netherlands, 2010; ISBN 978-90-481-9267-0.

48. Kharcheva, A.V.; Zhiltsova, A.A.; Lunina, O.N.; Krasnova, E.D.; Voronov, D.A.; Savvichev, A.S.; Patsaeva, S.V. Bacteriochlorophyll Fluorescence of Green Sulfur Bacteria in Anaerobic Zone of Two Natural Water Bodies. MOSCOW Univ. Phys. Bull. 2018, 73, 377-381. [CrossRef]

49. Zhiltsova, A.A.; Kharcheva, A.V.; Krasnova, E.D.; Lunina, O.N.; Voronov, D.A.; Savvichev, A.S.; Gorshkova, O.M.; Patsaeva, S.V. Spectroscopic Study of Green Sulfur Bacteria in Stratified Water Bodies of the Kandalaksha Gulf of the White Sea. Atmos. Ocean. Opt. 2018, 31, 390-396. [CrossRef]

50. Wiens, R.C.; Maurice, S.; Mccabe, K.; Cais, P.; Anderson, R.B.; Beyssac, O.; Bonal, L.; Clegg, S.; Deflores, L.; Dromart, G. The SuperCam remote sensing instrument suite for Mars 2020. In Proceedings of the 47th Lunar and Planetary Science Conference, The Woodlands, TX, USA, 21-25 March 2016; p. 1322.

51. Wiens, R.C.; Maurice, S.; Robinson, S.H.; Nelson, A.E.; Cais, P.; Bernardi, P.; Newell, R.T.; Clegg, S.; Sharma, S.K.; Storms, S.; et al. The SuperCam Instrument Suite on the NASA Mars 2020 Rover: Body Unit and Combined System Tests. Space Sci. Rev. 2021, 217, 1-87. [CrossRef] [PubMed]

52. Pershin, S.M. Possibility of relict organic pigment detection on the Mars surface from the Earth, Mars Orbiter or Lander. Suppl. Ann. Geophys. 1998, 16, C827-C1051.

53. DiGregorio, B.E. Spectroscopy; MJH Life Sciences: New York, NY, USA, 2000; pp. 48-50.

54. Pershin, S.M.; Pungin, V. Water on Mars: Anomaly of a water index (1042/953) on the surface of Mars in Arcadia Planitia (181 deg W, $37 \mathrm{deg}$ N). In Proceedings of the International Society for Optics and Photonics, San Diego, CA, USA, 29 July-3 August 2001; The Instruments, Methods, and Missions for Astrobiology IV.; 2002; Volume 4495, pp. 145-151.

55. Pershin, S.M.; Sobisevich, A.L.; Grishin, M.Y.; Gravirov, V.V.; Zavozin, V.A.; Kuzminov, V.V.; Lednev, V.N.; Likhodeev, D.V.; Makarov, V.S.; Myasnikov, A.V.; et al. Volcanic activity monitoring by unique LIDAR based on a diode laser. Laser Phys. Lett. 2020, 17, 115607. [CrossRef]

56. Blacksberg, J.; Alerstam, E.; Maruyama, Y.; Cochrane, C.J.; Rossman, G.R. Miniaturized time-resolved Raman spectrometer for planetary science based on a fast single photon avalanche diode detector array. Appl. Opt. 2016, 55, 739-748. [CrossRef] [PubMed]

57. Akbulut, M.; Kotov, L.; Wiersma, K.; Zong, J.; Li, M.; Miller, A.; Chavez-Pirson, A.; Peyghambarian, N. An Eye-Safe, SBS-Free Coherent Fiber Laser LIDAR Transmitter with Millijoule Energy and High Average Power. Photonics 2021, 8, 15. [CrossRef]

58. Hua, K.; Liu, B.; Chen, Z.; Fang, L.; Wang, H. Efficient and Noise Robust Photon-Counting Imaging with First Signal Photon Unit Method. Photonics 2021, 8, 229. [CrossRef] 